Journal of Business Finance and Economic (JBFE)

P-ISSN: 2746-6906

Volume 2, Nomor 2, Desember 2021

E-ISSN: $2746-6914$

https://journal.univetbantara.ac.id/index.php/jbfe

Journal of Business Finance and Economic (JBFE)

\title{
Pengaruh Good Corporate Governance (GCG) dan Coporate Social Responsbility (CSR) Terhadap Nilai Perusahaan
}

The Effect of Good Corporate Governance (GCG) and Corporate Social Responsibility (CSR) on Company Value

\author{
Purwanto Purwanto ${ }^{1}$ \\ Ardian Prima Putra ${ }^{2}$ \\ Gustita Arnawati Putri ${ }^{3}$ \\ Eka Pratiwi $^{4}$ \\ Universitas Veteran Bangun Nusantara ${ }^{1234}$ \\ anto.c412@gmail.com Epratiwi@gmail.com
}

\begin{abstract}
ABSTRAK: This pandemic seems to remind the importance of business continuity, that companies must pay attention to all internal and external stakeholders in order to increase company value. Good corporate governance or GCG is still one of the weaknesses that most companies in Indonesia have. The correct application of GCG can make a company bigger and more reliable. The purpose of this study is to determine the effect of projected GCG in institutional ownership, managerial ownership, audit committee and the Board of Commissioners and CSR on firm value. The sample in this study was 120 samples of data from manufacturing companies in the consumer goods industry sector. The results showed that the managerial ownership and CSR variables had a significant positive effect on firm value. The audit committee variable has a significant negative effect on firm value. and the variable of institutional ownership and the board of commissioners has no effect on firm value. and all independent variables together have a significant effect on firm value. Based on the results and analysis that has been carried out by researchers, hopefully this research can be useful for companies in increasing the value of the company by increasing the implementation of GCG and CSR disclosure and for investors to be taken into consideration in choosing issuers to invest.
\end{abstract}

Keyword : Good Corporate Governance, Corporate Social Responsbility, Nilai perusahaan 


\section{PENDAHULUAN}

Pemilik perusahaan tentu menginginkan perusahaannya mendapatkan laba yang tinggi, sehingga mampu meningkatkan kesejahteraan anggotanya dan meningkatkan nilai perusahaan. Meningkatnya nilai suatu perusahaan sangatlah penting bagi perusahaan. hal tersebut dapat ditandai dengan naiknya harga saham di pasar. Harga saham yang tinggi membuat nilai perusahaan juga tinggi, dan meningkatkan kepercayaan pasar tidak hanya terhadap kinerja perusahaan saat ini namun juga pada prospek perusahaan di masa mendatang (Sondokan,dkk, 2019). Hal ini dikarenakan nilai perusahaan merupakan gambaran mengenai seberapa baik atau buruknya manajemen dalam mengelola kekayaannya, bisa dilihat dari pengukuran kinerja keuangan dan faktor non keuangan yaitu penerapan Good Corporate governance (GCG) dan Corporate social responsbility (CSR). Fenomena pandemi covid-19 pada awal 2020 telah menimbulkan disrupsi dan menggeser berbagai tatanan kehidupan yang dikenal sebelumnya. Pandemi ini seolah mengingatkan pentingnya keberlangsungan bisnis, bahwa perusahaan harus memperhatikan semua stakeholders internal dan eksternal yang terdampak dari para pemegang saham, pegawai, hingga konsumen akhir. Tata kelola perusahaan yang baik atau GCG masih menjadi salah satu kelemahan yang dipunyai sebagian besar perusahaan di Indonesia. Penerapan Good Corporate Governance yang benar dapat membuat perusahaan semakin besar dan terpercaya. Penelitian (Ariyanti, dkk 2020) menyatakan bahwa kepemilikan manajerial berpengaruh signifikan terhadap nilai perusahaan, dan kepemilikan intitusional serta corporate social responsibility tidak berpengaruh signifikan terhadap nilai perusahaan. Penelitian tersebut diperkuat oleh penelitian (Triyono dan Setyadi 2015) yang menyatakan bahwa kepemilikan manajerial berpengaruh secara signifikan terhadap nilai perusahaan. Sedangkan,Dewan komisaris, komite audit dan corporate social responsibility tidak berpengaruh secara signifikan terhadap nilai perusahaan. Penelitian (Putri dan H Suprapto, 2016) menyatakan bahwa kepemilikan institusional, komite audit, dan pengungkapan CSR, Dewan Komisaris, Dewan direksi berpengaruh positif dan signifikan terhadap nilai perusahaan, berpengaruh negatif tidak signifikan terhadap nilai perusahaan. Berbeda pada penelitian Agustiani (2016) yang menyatakan bahwa hasil penelitian Dewan komisaris dan komite audit berpengaruh negatif dan signifikan terhadap nilai perusahaan. Penelitian yang dilakukan oleh Marius dan Masri (2017) menyatakan bahwa komite audit dan kepemilikan institusional menunjukkan pengaruh negatif terhadap nilai perusahaan. Perlu dijadikan perhatian dalam mekanisme corporate governance bahwa terdapat kepentingan baik dalam kepemilikan institusional maupun komite audit yang dapat berpengaruh kepada harga saham, sehingga menurunkan nilai perusahaan. Sedangkan, corporate social responsibility pada perusahaan manufaktur terbukti dapat meningkatkan nilai perusahaan. Hal ini menunjukkan bahwa faktor lingkungan sangat berpengaruh terhadap perusahaan manufaktur, dimana seperti diketahui dari pemberitaan, banyak perusahaan manufaktur yang merusak lingkungan sekitar perusahaan. Sehingga, apabila perusahaan manufaktur melakukan pengungkapan corporate social responsibility terhadap lingkungan akan mendapat respon positif oleh investor. Selain itu 
perusahaan manufaktur juga harus lebih meningkatkan perannya dalam pengungkapan corporate social responsibility dengan cara memperluas pengungkapan dalam bidang kemasyarakatan, konsumen, produk maupun ketenagakerjaan. Berdasarkan latar belakang diatas maka perumusan masalah dalam penelitian ini adalah : (1) apakah kepemilikan manajerial berpengaruh terhadap nilai perusahaan? (2) apakah kepemilikan institusioanl berpengaruh terhadap nilai perusahaan? (3) apakah Dewan Komisaris berpengaruh terhadap nilai perusahaan ? (4) apakah komite audit berpengaruh terhadap nilai perusahaan ? (5) apakah CSR berpengaruh terhadap nilai perusahaan?.

\section{KAJIAN PUSTAKA DAN PENGEMBANGAN HIPOTESIS}

\section{Nilai perusahaan}

Nilai perusahaan adalah kondisi tertentu yang telah dicapai sebuah perusahaan, sebagai gambaran yang telah dipercaya masyarakat. Meningkatnya nilai suatu perusahaan sangatlah penting bagi perusahaan. hal tersebut dapat ditandai dengan naiknya harga saham di pasar. Harga saham yang tinggi membuat nilai perusahaan juga tinggi, dan meningkatkan kepercayaan pasar tidak hanya terhadap kinerja perusahaan saat ini namun juga pada prospek perusahaan di masa mendatang (Sondokan,dkk, 2019).

\section{Kepemilikan Manajerial}

Kepemilikan manajerial adalah proporsi pemegang saham yang berasal dari pihak manajemen dan memiliki wewenang yang sama dengan pemegang saham lain dalam hal pengambilan keputusan. Proporsi kepemilikan manajerial yang semakin tinggi memberikan dampak positif bagi kinerja perusahaan, karena manajer akan berupaya semaksimal mungkin dalam mengelola perusahaan.

\section{Kepemilikan Institusional}

Kepemilikan institusional adalah suatu proporsi kepemilikan saham institusi dalam hal ini yaitu institusi pendiri perusahaan, bukan merupakan institusi pemegang saham publik yang diukur dengan presentase jumlah saham yang dimiliki oleh investor institusi intern.

\section{Dewan Komisaris}

Dewan komisaris merupakan mekanisme pengendalian intern tertinggi yang bertanggung jawab untuk memonitor tindakan manajemen puncak (Putri ayu Kemala, dkk,2016). Menurut peraturan yang dikeluarkan oleh BEI, jumlah Dewan Komisaris proposional sekurang-kurangnya 3 orang.

\section{Komite Audit}

Komite audit adalah auditor internal yang dibentuk dewan komisaris, yang bertugas melakukan pemantauan dan evaluasi atas perencanaan dan pelaksanaan pengendalian intern perusahaan. 


\section{Corporate Social Responsbility}

Corporate social responsibility merupakan bentuk tanggung jawab perusahaan dalam memperbaiki kesenjangan sosial dan kerusakan lingkungan yang terjadi akibat aktivitas operasional perusahaan. Semakin banyak bentuk pertanggungjawaban yang dilakukan perusahaan terhadap lingkungannya, image perusahaan menjadi meningkat.

\section{PENGEMBANGAN HIPOTESIS}

\section{Pengaruh kepemilikan manajerial terhadap nilai perusahaan}

Widyaningsih (2018) menyatakan bahwa kepemilikan manajerial berpengaruh positif dan signifikan terhadap nilai perusahaan. Pernyataan tersebut disetujui pada penelitian Ariyanti, dkk (2020) yang berpendapat bahwa kepemilikan manajerial berpengaruh positif signifikan terhadap nilai perusahaan. Sedangkan pada penelitian (Nole,dkk, 2017) berpendapat bahwa hasil penelitian kepemilikan manajerial berpengaruh negatif dan tidak signifikan. Peneliti cenderung sepakat dengan penelitian yang dilakukan oleh Widyaningsih (2018) dan Ariyanti, dkk (2020) bahwa kepemilikan manajerial berpengaruh positif dan signifikan terhadap nilai perusahaan, karena kepemilikan manajerial dipandang sebagai mekanisme kontrol yang tepat untuk mengurangi konflik keagenan dan Proporsi saham yang dikuasai manajer dapat mempengaruhi kebijakan perusahaan, Dengan demikian, kepentingan manajer dan pemegang saham akan bersatu dan akan berdampak positif dalam meningkatkan nilai perusahaan.

\section{H1: Kepemilikan Manajerial berpengaruh positif terhadap Nilai Perusahaan}

\section{Pengaruh Kepemilikan institusional terhadap nilai perusahaan}

Penelitian (Widyaningsih 2018) berpendapat bahwa kepemilikan institusional berpengaruh positif sinifikan terhadap nilai perusahaan. Sedangkan penelitian yang dilakukan oleh (Embang 2016) berpendapat bahwa kepemilikan institusional berpengaruh negatif terhadap nilai perusahaan.Peneliti cenderung sepakat dengan penelitian yang dilakukan oleh (Widyaningsih, 2018) yang menyatakan bahwa kepemilikan institusional berpengaruh positif dan signifikan terhadap nilai perusahaan, karena semakin tinggi tingkat kepemilikan institusional, maka semakin kuat tingkat pengendalian yang dilakukan pihak eksternal terhadap perusahaan, sehingga agency cost yang terjadi di dalam perusahaan semakin berkurang dan nilai perusahaan juga semakin meningkat.

\section{H2: Kepemilikan Institusional berpengaruh positif terhadap Nilai Perusahaan}

\section{Pengaruh Dewan Komisaris terhadap nilai perusahaan}

(Badruddien, 2017) menyatakan bahwa Dewan Komisaris berpengaruh positif terhadap nilai perusahaan. Hal ini menunjukkan pemantauan yang efektif terhadap manajemen yang 
dilakukan oleh dewan komisaris akan dapat membantu meminimalkan agency conflict yang akan berdampak pada nilai perusahaan. Berbeda dengan penelitian (Agustiani 2016) yang menyatakan bahwa ukuran Dewan Komisaris tidak berpengaruh terhadap nilai perusahaan, Penulis cenderung sepakat dengan penelitian (Badruddien,dkk, 2017) yang menyebutkan Dewan Komisaris berpengaruh terhadap nilai perusahaan. Karena, dengan adanya pengawasan yang baik akan meminimalisir tindakan kecurangan yang dilakukan manajemen dalam pelaporan keuangan. Dengan begitu, maka kualitas laporan keuangan juga semakin baik dan menyebabkan investor percaya untuk menanamkan modal di perusahaan tersebut. H3: Dewan Komisaris berpengaruh positif terhadap Nilai Perusahaan

\section{Pengaruh komite audit terhadap nilai perusahaan}

Penelitian (Amaliyah dan Herwiyanti 2019) berpendapat bahwa komite audit berpengaruh positif terhadap nilai perusahaan. Karena, komite audit mempunyai peran yang dapat meningkatkan pengawasan terhadap pelaporan keuangan yang dibuat oleh manajer. Berbeda dengan penelitian (Marius dan Masri 2017) yang menyatakan bahwa komite audit berpengaruh negatif terhadap nilai perusahaan. Penulis sepakat dengan penelitian yang dilakukan oleh (Widyasari, dkk 2015). Karena, jumlah komite audit yang semakin besar memungkinkan kualitas pelaporan semakin tinggi dan monitoring pihak manajemen akan semakin tinggi pula. Tingkat monitoring yang tinggi akan mampu meminimalkan kecurangan yang dilakukan ole$\mathrm{h}$ pihak manajemen.

\section{H4: Komite Audit berpengaruh positif terhadap Nilai Perusahaan}

\section{Pengaruh CSR terhadap nilai perusahaan}

Penelitan (Fauzi, dkk 2016) dan penelitian (Embang 2016) berpendapat bahwa corporate social responsibility berpengaruh positif terhadap nilai perusahaan. Berbeda dengan penelitian (Ariyanti, dkk 2020) yang menyatakan bahwa corporate social responsibility tidak berpengaruh terhadap nilai perusahaan. Penulis sepakat dengan penelitian yang dilakukan oleh (Fauzi, dkk 2016) serta (Embang 2016) yang menyatakan bahwa corporate social responsibility berpengaruh terhadap nilai perusahaan, karena dengan meningkatnya pengungkapan corporate social responsibility yang dilakukan oleh perusahaan akan menciptakan citra yang baik terhadap perusahaan, sehingga investor akan melihat hal ini sebagai hal yang positif untuk berinvestasi di perusahaan tersebut.

H5: Corporate Social Responsibility berpengaruh positif terhadap Nilai Perusahaan. 


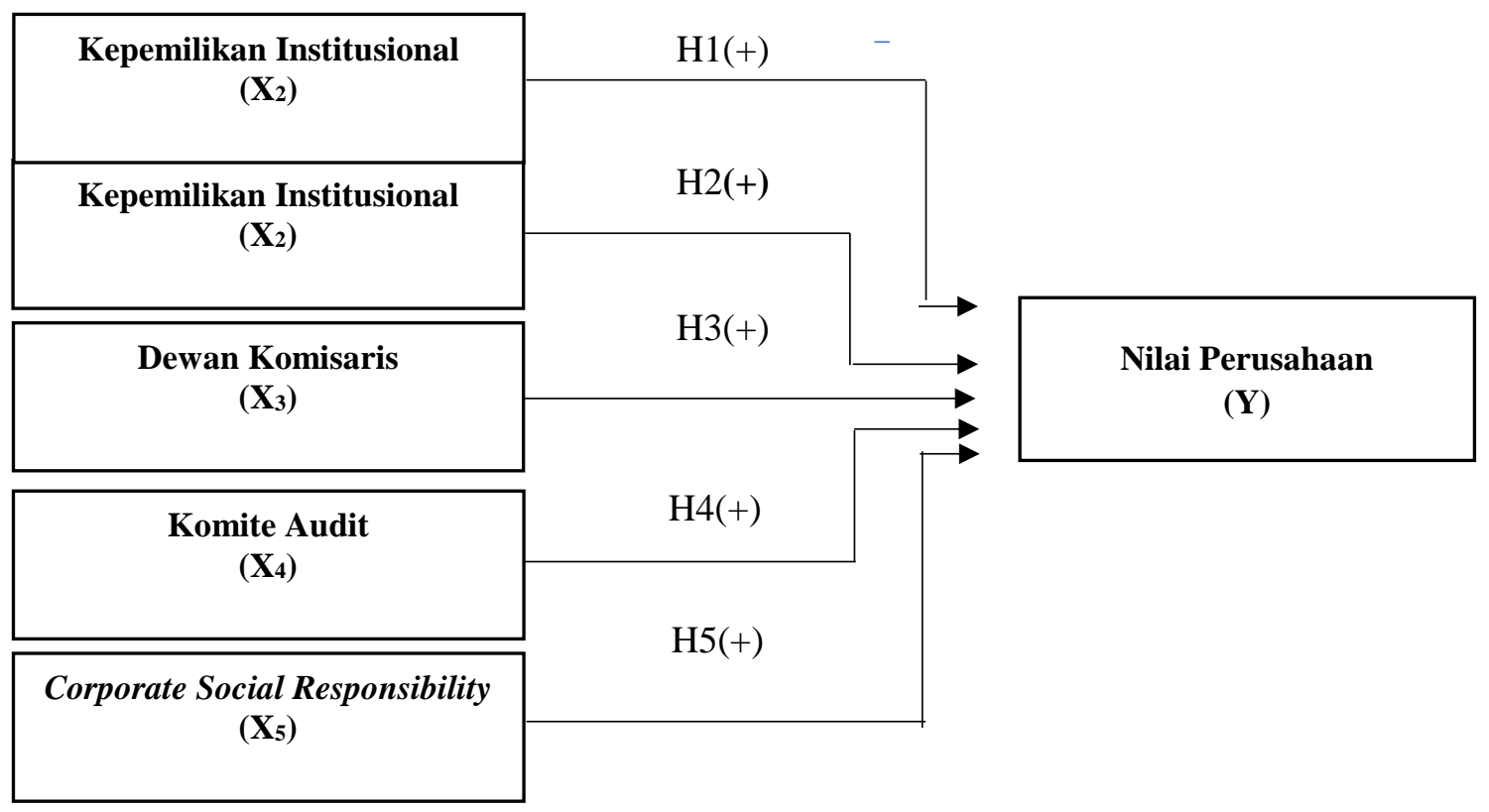

Gambar 2.1

Model Hipotesis

\section{METODE PENELITIAN}

Populasi yang menjadi objek penelitian ini yaitu perusahaan manufaktur sektor industri barang konsumsi yang telah terdaftar di Bursa Efek Indonesia (BEI) yang menerbitkan laporan tahunan setiap tahun selama periode penelitian 2017-2020. Sampel penelitian ini dengan menggunakan metode purposive sampling, merupakan teknik penentuan sampel dengan pertimbangan tertentu, yaitu dengan kriteria sebagai berikut:

a. perusahaan manufaktur sektor industri barang konsumsi yang terdaftar di Bursa Efek Indonesia tahun 2017-2020.

b. seluruh perusahaan manufaktur sektor industri barang konsumsi yang laporan keuangannya go public dan telah diaudit.

c. perusahaan manufaktur sektor industri barang konsumsi yang menerbitkan laporan keuangan tahunan (annual report) secara konsisten dan lengkap pada tahun 20172020.

d. perusahaan yang memiliki data lengkap terkait dengan variabel penelitian 


\section{Definisi Operasional dan pengukuran Variabel}

\section{Nilai perusahaan}

Nilai perusahaan adalah kondisi tertentu yang telah dicapai sebuah perusahaan, sebagai gambaran yang telah dipercaya masyarakat. Salah satu alternatif yang dapat digunakan untuk mengukur nilai perusahaan adalah rasio PBV, rasio tersebut dapat diukur menggunakan rumus sebagai berikut:

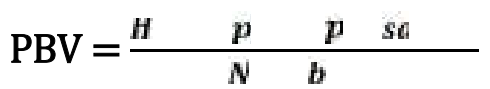

\section{Kepemilikan manajerial}

Kepemilikan manajerial adalah proporsi pemegang saham yang berasal dari pihak manajemen dan memiliki wewenang yang sama dengan pemegang saham lain dalam hal pengambilan keputusan. Rumus untuk menghitung kepemilikan manajerial adalah sebagai berikut :

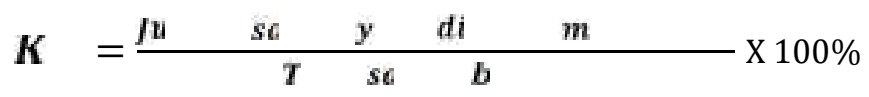

\section{Kepemilikan Institusional}

Marius dan Masri (2017) mengemukakan bahwa kepemilikan institusional merupakan suatu keadaan dimana suatu institusi tersebut mempunyai saham dalam suatu perusahaan. Institusi tersebut dapat berupa institusi swasta, institusi domestik, asing, maupun pemerintah sendiri dan besar kepemilikan saham lebih dari 5\%. Variabel kepemilikan institu sional (KI) dalam penelitian ini diukur menggunakan rumus sebagai berikut:

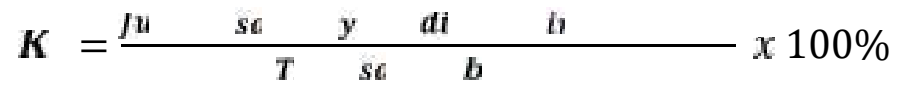

\section{Dewan Komisaris}

Dewan komisaris adalah mereka yang bukan merupakan anggota manajemen, pemegang saham mayoritas, dan pejabat atau interkoneksi atau tidak langsung dengan pemegang saham mayoritas dari perusahaan yang mengawasi manajemen perusahaan tersebut (Gosal, dkk, 2018). Variabel Dewan Komisaris diukur dengan jumlah keseluruhan anggota dewan 
komisaris yang terdapat di perusahaan. Dalam penelitian ini diukur dengan menggunakan rumus sebagai berikut (Badruddien, dkk, 2017):

$$
D=\sum \text { Dewan Komisaris }
$$

\section{Komite Audit}

Ikatan Komite Audit Indonesia (IKAI) mendefinisikan komite audit adalah suatu komite yang bekerja secara professional dan independent yang dibentuk oleh dewan komisaris dan dengan demikian, tugasnya adalah membantu dan memperkuat fungsi dewan komisaris atau dewan pengawas dalam menjalankan fungsi pengawasan (oversight) atas proses pelaporan keuangan, manajemen resiko, pelaksanaan audit, dan implementasi dari corporate governance di perusahaan-perusahaan. (Marius dan Masri, 2017) Komite audit dalam penelitian ini diukur dengan menggunakan rumus sebagai berikut:

K\$

\section{Corporate Social Responsbility}

Corporate social responsibility merupakan bentuk tanggung jawab perusahaan dalam memperbaiki kesenjangan sosial dan kerusakan lingkungan yang terjadi akibat aktivitas operasional perusahaan. (Triyono dan Setyadi, 2015).Untuk pengukuran variabel pengungkapanCSR dalam penelitian ini menggunakan CSRDI atau Corporate sosial responbility Disclousure Index yang didasarakan pada pedoman GRI yang meliputi 3 kategori yang dibagi ke 91 item, persamaan CSR dengan menurut pedoman GRI :

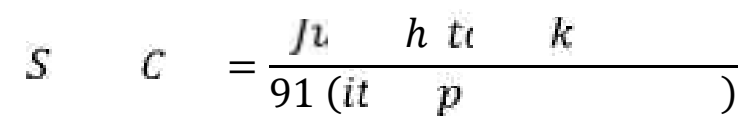

\section{Metode Analisis}

Model pengujian dalam penelitian ini akan dinyatakan dalam persamaan dibawah ini:

$$
\mathrm{NP}=\alpha+\mathrm{b} 1 \mathrm{KM}+\mathrm{b} 2 \mathrm{KI}+\mathrm{b} 3 \mathrm{IDK}+\mathrm{b} 4 \mathrm{KA}+\mathrm{b} 5 \mathrm{CSR}+\mathrm{e}
$$

Keterangan:

$\mathrm{NP}=$ Nilai Perusahaan

$\alpha=$ Konstanta

b1-b4 = Koefisien regresi

$\mathrm{KM}=$ Kepemilikan Manajerial

$\mathrm{KI}=$ Kepemilikan Institusional

DK $=$ Dewan Komisaris 
$\mathrm{KA}=$ Komite Audit

CSR $=$ Corporate Social Responsibility

$\mathrm{e}=$ error

\section{HASIL DAN PEMBAHASAN}

\section{Statistik Deskriptif}

\begin{tabular}{|c|c|c|c|c|c|}
\hline \multicolumn{6}{|c|}{ Descriptive Statistic } \\
\hline & $N$ & Minimum & Maximum & Mean & Std Deviation \\
\hline KM & 120 & 0,00 & 38,42 & 1,2648 & 4,1291 \\
\hline KI & 120 & 0,00 & 100 & 49,5213 & 34,2807 \\
\hline DK & 120 & 2,00 & 8,00 & 3,8080 & 1,4511 \\
\hline KA & 120 & 2,00 & 6,00 & 3,0250 & 0,5098 \\
\hline CSR & 120 & 0,08 & 0,53 & 0,3293 & 0,1073 \\
\hline Nilai & 120 & 0,00 & 38,38 & 2,6180 & 4,5843 \\
\hline Perusahaan & & & & & \\
\hline
\end{tabular}

Dependen : Nilai Perusahan

hasil uji analisis deskriptif yang dilakukan pada sebanyak 120 data. Variabel KM memiliki nilai minimum sebesar 0,00 dan nilai maksimum 38,42 dengan rata-rata 1,2648 dan nilai standar deviasi sebesar 4,1291. Variabel KI memiliki nilai minimum sebesar 0,00 dan nilai maksimum 100 dengan rata-rata 49,5213 dan nilai standar deviasi sebesar 34,2807. Variabel DK memiliki nilai minimum sebesar 2,00 dan nilai maksimum 8,00 dengan rata-rata 3,8080 dan nilai standar deviasi sebesar 1,4511. Variabel KA memiliki nilai minimum sebesar 2,00 dan nilai maksimum 6,00 dengan rata-rata 3,0250 dan nilai standar deviasi sebesar 0,5098. Variabel CSR memiliki nilai minimum sebesar 0,08 dan nilai maksimum 0,53 dengan ratarata 0,3293 dan nilai standar deviasi sebesar 4,5843.

\section{Uji Hipotesis}

\section{Hasil Uji Regresi Linear Berganda}

\begin{tabular}{|c|c|c|c|c|c|c|}
\hline & \multicolumn{6}{|c|}{ Coefficients $^{a}$} \\
\hline & \multirow[b]{3}{*}{ Model } & \multicolumn{2}{|c|}{ Unstandardized Coefficients } & \multirow{3}{*}{$\begin{array}{c}\text { Stantardized } \\
\text { Coefficients }\end{array}$} & \multirow{3}{*}{$\mathrm{t}$} & \multirow{3}{*}{ Sig. } \\
\hline & & & & & & \\
\hline & & B & Std. Error & & & \\
\hline \multirow[t]{6}{*}{1} & (Constant) & 1,286 & 0,258 & & 4,988 & 0,000 \\
\hline & KM & 0,145 & 0,065 & 0,190 & 2,230 & 0,028 \\
\hline & $\mathrm{KI}$ & 0,012 & 0,006 & 0,169 & 1,940 & 0,055 \\
\hline & DK & $-0,091$ & 0,058 & $-0,137$ & $-1,563$ & 0,121 \\
\hline & KA & $-0,576$ & 0,151 & $-0,340$ & $-3,805$ & 0,000 \\
\hline & CSR & 0,318 & 0,152 & 0,176 & 2,094 & 0,038 \\
\hline
\end{tabular}


https://journal.univetbantara.ac.id/index.php/jbfe

Dependen : Nilai Perusahaan

Berdasarkan hasil uji hipotesis, diperoleh jawaban hipotesis sebagai berikut:

\section{Hipotesis 1}

Hasil pengujian dari hipotesis pertama dapat disimpulkan bahwa kepemilikan manajerial (KM) berpengaruh positif terhadap nilai perusahaaan. Hasil penelitian ini dapat ditunjukkan dalam nilai signifikansi sebesar 0,028 yang artinya nilai dari signifikasinya kurang dari 0,05 , maka dari itu hipotesis diterima. Hasil penelitian ini sejalan dengan penelitian yang dilakukan oleh peneliti Ariyanti, dkk (2020).

\section{Hipotesis 2}

Hasil pengujian dari hipotesis kedua dapat disimpulkan bahwa kepemilikan institusional tidak berpengaruh terhadap nilai perusahaan. Hasil dari penelitian ini dapat ditunjukkan di dalam nilai signifikansi sebesar 0,055 yang artinya nilai signifikan lebih dari 0,05, maka dari itu hipotesis ditolak. Hasil penelitian ini sejalan dengan penelitian Amaliyah dan Herwiyanti (2019).

\section{Hipotesis 3}

Hasil pengujian dalam hipotesis ketiga ini dapat disimpulkan bahwa dewan komisaris tidak berpengaruh terhadap nilai perusahaan. Hasil penelitian ini dapat ditunjukkan dalam nilai signifikansi sebesar 0,121, yang artinya nilai signifikannya lebih dari 0,05, maka dari itu hipotesis ditolak. Hasil penelitian ini sejalan dengan penelitian yang dilakukan oleh peneliti Gosal, dkk (2018) yang menyatakan bahwa dewan komisaris tidak berpengaruh terhadap nilai perusahaan.

\section{Hipotesis 4}

Hasil pengujian dalam hipotesis keempat ini dapat disimpulkan bahwa komite audit berpengaruh negatif terhadap nilai perusahaan. Hasil penelitian ini dapat ditunjukkan dalam nilai signifikansi sebesar 0,000 yang artinya nilai signifikannya lebih kecil dari 0,05 , maka dari itu hipotesis ditolak Hal ini sejalan dengan penelitian Marius dan Masri (2017) yaitu komite audit berpengaruh negatif dan signifikan terhadap nilai perusahaan.

\section{Hipotesis 5}

Hasil pengujian dalam hipotesis kelima ini dapat disimpulkan bahwa corporate social responsibility (CSR) berpengaruh positif terhadap nilai perusahaan. Hasil penelitian ini ditunjukkan dalam nilai signifikansi sebesar 0,038 yang artinya nilai signifikannya lebih kecil dari 0,05, maka dari itu hipotesis diterima. Penelitian ini sejalan dengan penelitian yang dilakukan oleh Fauzi, dkk (2016) serta Embang (2016) yang menyatakan bahwa corporate social responsibility berpengaruh terhadap nilai perusahaan, 


\section{KESIMPULAN DAN SARAN}

\section{Kesimpulan}

Penelitian ini bertujuan untuk mengetahui pengaruh kepemilikan manajerial, kepemilikan institusional, dewan komisaris, komite audit, dan corporate social responsibility, studi pada perusahaan manufaktur sektor industri barang konsumsi yang terdaftar di bursa efek Indonesia periode tahun 2017-2020. Berikut ini merupakan kesimpulan yang dapat ditarik dari hasil pengujian yang telah dilakukan:

a. Hasil pengujian di hipotesis pertama dapat disimpulkan bahwa kepemilikan manajerial berpengaruh positif terhadap nilai perusahaaan. Hasil penelitian ini dapat ditunjukkan dalam nilai signifikansi sebesar 0,028 yang artinya nilai dari signifikasinya kurang dari 0,05, maka dari itu hipotesis H1 diterima.

b. Hasil pengujian di hipotesis kedua dapat disimpulkan bahwa kepemilikan institusional tidak berpengaruh terhadap nilai perusahaan. Hasil dari penelitian ini dapat ditunjukkan di dalam nilai signifikansi sebesar 0,055 yang artinya nilai signifikan lebih dari 0,05, maka dari itu hipotesis $\mathbf{H 2}$ ditolak.

c. Hasil pengujian di hipotesis ketiga dapat disimpulkan bahwa dewan komisaris tidak berpengaruh terhadap nilai perusahaan. Hasil penelitian ini dapat ditunjukkan dalam nilai signifikansi sebesar 0,121, yang artinya nilai signifikannya lebih dari 0,05, maka dari itu hipotesis $\mathbf{H 3}$ ditolak.

d. Hasil pengujian di hipotesis keempat dapat disimpulkan bahwa komite audit berpengaruh negatif signifikan terhadap nilai perusahaan. Hasil penelitian menunjukkan nilai signifikasi variabel komite audit sebesar 0,000 yang artinya kurang dari 0,05. Maka dari itu hipotesis H4 Ditolak

e. Hasil pengujian di hipotesis kelima dapat disimpulkan bahwa corporate social responsibility berpengaruh positif terhadap nilai perusahaan. Hasil penelitian ini ditunjukkan dalam nilai signifikansi sebesar 0,038 yang artinya nilai signifikannya lebih kecil dari 0,05, maka dari itu hipotesis $\mathbf{H 5}$ diterima.

\section{Saran}

Berdasarkan hasil dan analisis yang telah dilakukan oleh peneliti, semoga penelitian ini dapat bermanfaat bagi perusahaan maupun investor. Berikut saran dari penulis untuk penelitian selanjutnya: 
a. Penelitian selanjutnya diharapkan bisa memperbanyak jumlah sampel perusahaan, selain itu untuk tahun periode pengamatan selanjutnya diharapkan lebih diperpanjang dan terbaru.

b. Penelitian selanjutnya diharapkan menambah atau mengganti faktor lain sebagai variabel independen yang dapat mempengaruhi nilai perusahaan.

\section{REFERENCES}

Agustiani, Rizki Muti.2016. Pengaruh Good Corporate Governance, Return On Asset, Return On Equity, Bopo, Dan Capital Adequacy Ratio Terhadap Nilai Perusahaan Go Public Di Bursa Efek Indonesia. Jurnal Ekonomi Bisnis. Vol 21. No 2.

Amaliyah, Fitri, dan Eliada Herwiyanti. 2019. Pengaruh Kepemilikan Institusional, Dewan Komisaris Independen, Dan Komite Audit Terhadap Nilai Perusahaan Sektor Pertambangan. Jurnal Akuntansi, Vol. 9, No. 3, Hal. 187-200.

Ariyanti, Feby, Siti Nurlaela, dan Anita Wijayanti. 2020. Kepemilikan Manajerial, Kepemilikan Institusional, Corporate Social Responsibility Dan Nilai Perusahaan Pertambangan Batu Bara Periode 2014-2018 Yang Terdaftar di Bursa Efek Indonesia. Jurnal Akuntansi, Voume 6 Nomor 1, Hal. 48-58.

Badruddien, Yusuf;Tieka Trikartika Gustyana;Andrieta Shintia. 2017. Pengaruh Good Coporate Governance, leverage dan ukuran perusahaan terhadap nilai perusahaan (studi empiris pada perusahaan industri barang konsumsi di BEI periode 2012-2015. Jurnal e-procedding of management. Vol 4. No 3.

Embang, Elvina Lidya. 2016. Pengaruh CSR dan GCG Terhadap Nilai Perusahaan Sektor Manufaktur Yang Terdaftar di BEI Tahun 2010-2014. Parsimonia Vol. 2 No. 3

Fauzi, Armi Sulthon, Ni Ketut Suransi, dan Alamsyah. 2016. Pengaruh GCG dan CSR Terhadap Nilai Perusahaan dengan Profitabilitas Sebagai Variabel Pemoderasi. Jurnal Investasi. Vol 12 No 1. Hal 1-19.

Gosal, Melisa Maria, Sifrid S. Pangemanan, dan Maria V.J. Tielung. 2018. The Influence of Good Corporate Governance on Firm Value: Empirical Study of Companies Listed in IDX 30 Index Within 2013-2017 Period. Jurnal EMBA. Vol.6 No.4, Hal. 2688-2697

Marius, Maureen Erna, dan Indah Masri. 2017. Pengaruh Good Corporate Dan Corporate Social Responsibility Terhadap Nilai Perusahaan. Konferensi Ilmiah Akuntansi IV. 2-3 Maret 2017.

Nole, Veronika; Luh Komang Merawati; I Putu Edy Arizona. 2021. Pengaruh Mekanisme Corporate Governance Terhadap Nilai Perusahaan Pada Perusahaan Manufaktur Yang Terdaftar Di Bursa Efek Indonesia Periode 2016-2018. Jurnal Karma. Vol. 1, No 3 
Putri, Ayu Kemala, Made Sudarma, Bambang Purnomosidhi. 2016. Pengaruh Corporate social responbility terhadap nilai perusahaan dengan ukuran perusahaan dan jumlah dewan komisaris sebagai variabel pemoderasi. Jurnal aplikasi manajemen. Vol 12, No 2.

Putri, Ida Ayu Sasmika dan Bambang Suprasto H. 2016. Pengaruh Tanggung Jawab Sosial Perusahaan Dan Mekanisme Tata Kelola Perusahaan Terhadap Nilai Perusahaan. Ejurnal Akuntansi Universitas Udayana. Vol.15.1

Sondokan, Nathalia V et all. 2019. Pengaruh dewan komisaris Independen, Dewan Direksi, dan Komite Audit terhadap nilai perusahaan yang terdaftar di BEI periode 2014-2017. Jurnal EMBA, Vol 7, No 04.

Triyono, Febi, dan Edi Joko Setyadi. 2015. Pengaruh Good Corporate Governance, Dan Pengungkapan Corporate Social Responsibility Terhadap Nilai Perusahaan (Pada Perusahaan Property and Real Estate Yang Terdaftar di BEI). Kompartemen, Vol. XIII No. 1.

Widyaningsih, Dewi. 2018. Kepemilikan Manajerial, Kepemilikan Institusional, Komisaris Independen, Serta Komite Audit Pada Nilai Perusahaan Dengan Pengungkapan CSR sebagai Variabel Moderating dan Firm Size sebagai Variabel Kontrol. Jurnal Akuntansi dan Pajak, 19(01), 2018, 38-52. 